\title{
Towns, government, legislation and the 'police' in Jamaica and the British Atlantic,
} 1770-1805 1

The process of urban renewal in the British Isles in the long eighteenth century was based, at least in part, on new structures of urban government made possible by the growing power of Parliament. Paving, lighting and improvement commissions in England and Ireland were created by parliamentary legislation and enabled residents to overhaul the urban fabric, while 'police' commissions were created for Scottish towns which provided municipal authorities with wide-ranging social and economic powers for the regulation of urban life. Recent work has emphasised the importance of such factors even further afield in colonial towns such as Charleston, where the power of the colonial assembly was used to establish similar structures to oversee urban society. Urban renewal was therefore a transatlantic process grounded partly on the growing ability of British metropolitan, provincial and colonial legislatures to supply legislation for the purpose of urban reform. Focussing on the development of urban government in Jamaica, in particular between 1770 and 1805 when legislation was passed for the 'policing' - in the broader Scottish sense of the term - its major towns, suggests that Jamaica and the region as a whole was also part of these broader processes of both urban renewal and legislation expansion which persisted and even intensified in the postrevolutionary British Atlantic after 1783. Beginning in 1781, urban elites in Jamaica began to adopt 'police' powers which offered comprehensive powers of municipal government to address problems not faced by rural parishes, and which stretched beyond the mere maintenance of public order. However, the process was marked as much by diversity and discontinuity. Whereas in Britain and North America the problems to be addressed were

\footnotetext{
${ }^{1}$ I am grateful to Trevor Burnard, Rosemary Sweet and the reviewers at Urban History, and the attendees at the Urban History Conference 2018 for their advice and encouragement in writing this article. The research was supported by a British Academy Postdoctoral Fellowship, with further assistance from a Leverhulme Trust Early Career Fellowship.
} 
overwhelmingly those of urban renewal, in Jamaica the towns feared foreign invasion, internal revolt and the dissolution of the slave society and racial order. Their police acts show the alternative pathways urban modernity could take in the British Atlantic world.

\section{Background}

From the late seventeenth century English towns and cities experienced an 'urban renaissance', beginning a long phase of urbanisation which led to the active and transformative civic movement of the nineteenth century. As Peter Borsay, Penelope Corfield, Rosemary Sweet and others have shown, this involved the improvement of the urban fabric, including public health and public order, and the gentrification of the wider urban environment in line with new English and European ideals of civility, politeness, sociability, rationality and order. ${ }^{2}$ Though this was ultimately rooted in changing popular ideas and expectations about the urban experience, it was largely effected with the adoption of new political powers by urban elites, either through existing municipal governments, voluntary societies and associations, or by the statutory commission, which represented a blend of all three. First described by the Webbs in their historical survey of eighteenth century local government, and since examined in more depth by Paul Langford, Joanna Innes and others, these bodies were incorporated by parliamentary statute and were empowered to levy rates from the local urban population and spend them on various urban improvements. ${ }^{3}$

\footnotetext{
${ }^{2}$ Peter Borsay, The English urban renaissance:culture and society in the provincial town, 1660-1770 (Oxford, 1989); P. J. Corfield, The impact of English towns, 1700-1800 (Oxford, 1982); Rosemary Sweet, The English town, 1680-1840: government, society and culture (Harlow, 1999) pp. 40-61, 76-109. For a summary of this historiography, see Peter Clark and Michele Gillespie, 'Introduction', in Peter Clark and Michele Gillespie (eds.), Two capitals: London and Dublin, 1500-1840 (Oxford, 2001) pp. 1-6; Peter Borsay and L. J. Proudfoot, 'The English and Irish urban experience, 1500-1800: change, convergence and divergence', in Peter Borsay and L. J. Proudfoot (eds.), Provincial towns in early modern England and Ireland: change, convergence and divergence (Oxford, 2002) pp. 1-27

${ }^{3}$ Sidney Webb and Beatrice Webb, English Local Government: statutory authorities for special purposes $(9$ vols., London, 1922); Joanna Innes, 'Managing the metropolis: London's social problems and their control, c. 1660-1830', in Peter Clark and Michele Gillespie (eds.), Two capitals: London and Dublin, 1500-1840 (Oxford,
} 
They were representative of a wider shift in political power in this period as interest groups of various kinds throughout England made increasing use of parliamentary legislation to address the problems they faced, contributing to the enormous upsurge in overall output from 1688 identified by Julian Hoppit. ${ }^{4}$ A very similar process took place in Ireland in this period as urban elites used the burgeoning powers of the autonomous Irish parliament to create statutory bodies, such as the Wide Streets Commission for Dublin in 1757 and the Dublin Paving Board in 1774, to facilitate urban renewal. ${ }^{5}$ Political - and in particular legislative power therefore enabled this process. Other parts of the British Atlantic showed greater diversity in forms and structures, even if the underlying principles and processes were largely the same in all these places.

For example, recent work by Bob Harris, Charles McKean, James Barrie and others has helped to demonstrate a similar process occurring in Scottish towns across the same period, but whereas in England this was usually through a mass of overlapping statutory commissions, in Scotland the main vehicle from the 1780s onwards was the 'police' commission. ${ }^{6}$ As elected bodies that operated alongside the existing burghal authorities, the police commissions reflected an older sense of 'policing' in Scotland, England and Europe as

2001) pp. 53-79; Paul Langford, Public life and the propertied Englishman, 1689-1798 (Oxford, 1991) pp. 1823, 208, 223-32, 249-50; Sweet, English town, pp. 61-101

${ }^{4}$ Julian Hoppit, 'Patterns of parliamentary legislation, 1660-1800', Historical Journal, 39 (1996) pp. 109-31; Sweet, English town, pp. 67-73. For other examples of interest groups using legislation, see Stuart Handley, 'Local legislative initiatives for economic and social development in Lancashire, 1689-1731', Parliamentary History, 9 (1990) pp. 14-37; Joanna Innes, 'The local acts of a national Parliament: Parliament's role in sanctioning local action in eighteenth-century Britain', in Joanna Innes (ed.), Inferior politics: social problems and social policies in eighteenth-century Britain (Oxford, 2009) pp. 78-108; and the essays in Perry Gauci, Regulating the British economy, 1660-1850 (Farnham, 2011)

${ }^{5}$ Jacqueline Hill, 'The shaping of Dublin government in the long eighteenth century', in Peter Clark and Michele Gillespie (eds.), Two capitals: London and Dublin, 1500-1840 (Oxford, 2001) pp. 160-2; Colm Lennon, 'The changing face of Dublin, 1550-1750', in Peter Clark and Michele Gillespie (eds.), Two capitals: London and Dublin, 1500-1840 (Oxford, 2001) pp. 45-60; Edel Sheridan-Quantz, 'The multi-centred metropolis: the social topography of eighteenth century Dublin', in Peter Clark and Michele Gillespie (eds.), Two capitals: London and Dublin, 1500-1840 (Oxford, 2001) pp. 275-87; Finnian Ó Cionnaith, Exercise of authority: surveyor Thomas Owen and the paving, cleansing and lighting of Georgian Dublin (Dublin, 2016) ${ }^{6}$ Bob Harris and Charles McKean (eds.), The Scottish town in the Age of the Enlightenment, 1740-1820 (Edinburgh, 2014) pp. 78-134, 151-208 
a term that related not just to law enforcement or even public order but also social and moral regulation, the management of urban society and the various relationships within it. ${ }^{7}$ Davie Barrie has recently argued that this particular understanding of 'policing' as a comprehensive urban moral solution had its roots in a distinctively Scottish tradition of urban intervention, refined through key figures in the Scottish Enlightenment such as David Hume, Adam Smith and Adam Ferguson into a practice of civic empowerment, where the municipal space was an arena for the cultivation of political participation by the informed urban citizen. ${ }^{8}$

Parliamentary legislation was therefore increasingly used in Scotland after the 1780s to provide a distinctive local solution to urban problems that integrated the Scottish municipal environment into British norms. ${ }^{9}$ Work on the colonial towns of British North America has identified similar processes of urban renewal up to 1783 which likewise helped colonial elites see themselves as provincial Britons, though only Emma Hart has pointed out how in towns such as Charleston this was made possible in part by a statutory commission, which the residents secured in 1732. ${ }^{10}$ While changes were made to adapt British models of urban renewal to conditions in Charleston, not least with wide-ranging powers for the control of free and enslaved people of colour, Hart argues that this legislation nevertheless gave the city 'membership in a larger British Atlantic movement of urban improvement, making it a participant in a transatlantic enlightened drive for order, cleanliness and modernity'. ${ }^{11}$ This

\footnotetext{
${ }^{7}$ David G. Barrie, Police in the age of improvement: police development and the civic tradition in Scotland, 1775-1865 (Cullompton, 2008), esp. pp. 93-114. For the origins of the term, see Barrie, Police development, pp. $12,13,267$

${ }^{8}$ Harris and Mckean (eds.), Scottish town, pp. 428-66; Graeme Morton, 'Civil society, municipal government and the state: enshrinement, empower and legitimacy, Scotland 1800-1929', Urban History, 25 (1998) pp. 34867; Barrie, Police development, pp. 77-83 and, for more detail, David G. Barrie, 'Police in civil society: police, Enlightenment and civic virtue in urban Scotland, c. 1780-1833', Urban History, 37 (2010) pp. 45-65. For a similar process in England, see Francis M. Dodsworth, 'Civic' police and the condition of liberty: the rationality of governance in eighteenth-century England', Social History, 29 (2004) pp. 199-216

${ }^{9}$ Harris and Mckean (eds.), Scottish town, pp. 489-504

${ }^{10}$ Emma Hart, Building Charleston: town and society in the eighteenth-century British Atlantic world (London, 2010) pp. 67-97, 157-83; Emma Hart, 'City government and the state in eighteenth-century South Carolina', Eighteenth Century Studies, 50 (2017) pp. 195-211.

${ }^{11}$ Hart, Building Charleston, p. 159
} 
then continued after 1783 as cities in the early Republic used new federal, state and municipal powers to accelerate the process of urban improvement and political education. ${ }^{12}$

Towns in England, Ireland, Scotland and America therefore experienced a common urban renaissance which had spread to the metropolitan and colonial peripheries by the mid- to late eighteenth century and relied on the new powers of local legislatures to support or promote broader social and cultural change. Looking at urban renewal in Jamaica between 1770 and 1805 shows that this urban renaissance extended even into the British West Indies, that local circumstances caused it to evolve in a different direction, but that it was enabled by a similar culture of legislative empowerment. ${ }^{13}$ This link between urban renewal and legislation in Jamaica has been overlooked though, mainly due to a lack of sustained engagement with the legislative practices of colonial assemblies in this part of the British Atlantic beyond their slave codes. ${ }^{14}$ Studies of Bridgetown in Barbados by Pedro Welch, of Spanish Town by James Robertson, and of Kingston by Wilma Bailey, Jack Greene, Barry Higman, Colin Clarke, Trevor Burnard and Lorna Simmonds have dealt mainly with their demography, society, economy and culture without engaging with issues of urban renewal and political empowerment. ${ }^{15}$ Work on the 'black urban Atlantic' has mainly focussed on subaltern

\footnotetext{
12 Joel A. Tarr, 'The evolution of urban infrastructure in the nineteenth and twentieth centuries', in Royce Hanson (ed.), Perspectives on urban infrastructure (Washington, DC, 1984) pp. 4-21; John Lauritz Larson, Internal improvement: national public works and the promise of popular government in the early United States (Chapel Hill, NC, 2001)

${ }^{13}$ Aaron Graham, 'Jamaican legislation and the transatlantic constitution, 1664-1839', Historical Journal, 61 (2018) pp. 327-55 and idem., 'Legislatures, legislation and legislating in the British Atlantic, 1692-1800', Parliamentary History, 37 (2018)

${ }^{14}$ Elsa V. Goveia, Slave society in the British Leeward Islands at the end of the eighteenth century (New Haven, $1965)$ pp. 152-202; Bernard Marshall, Slavery, law and society in the British Windward Islands, 1743 - 1823: a comparative study (Kingston, Jamaica, 2007) pp. 120-42; Graham, 'Jamaican legislation', pp. 327-55

${ }^{15}$ Pedro L.V. Welch, Slave society in the city: Bridgetown, Barbados 1680-1834 (Kingston, 2004); James Robertson, Gone is the ancient glory: Spanish Town, Jamaica, 1534-2000 (Kingston; Miami, 2005); Jack P. Greene, Settler Jamaica in the 1750s: a social portrait (Charlottesville, VA, 2016) pp. 110-76; B.W. Higman, Slave population and economy in Jamaica, 1807-1834 (Cambridge, 1976); B.W. Higman, Slave populations of the British Caribbean, 1807-1834 (Baltimore; London, 1984) pp. 226-59; Trevor G. Burnard, “"The Grand Mart of the Island": the economic function of Kingston, Jamaica, in the mid-eighteenth century', in Kathleen Monteith and Glen Richards (eds.), Jamaica in slavery and freedom: history, heritage and culture (Kingston, 2002) pp. 225-41; B. W. Higman, 'Jamaica port towns in the early nineteenth century', in F.W. Knight and P.K.
} 
experiences rather than the structures of law, order and municipal governance in the British West Indies, though Wilma Bailey and Lorna Simmons have offered several short studies of social control in Kingston during the eighteenth century. ${ }^{16}$ Neither explored though its transatlantic context, especially the analogous developments of 'police' laws in Jamaica and Scotland. Only Burnard and Hart have situated these towns in their wider contexts, arguing that Kingston and Charleston 'participate[d] in recognisable processes of urban modernisation ... [and] were connected to wider patterns of urbanisation in the British Atlantic' which, like many other processes in this region, continued beyond $1783 .{ }^{17}$ Although very little material now remains to show this process worked itself out in Jamaica, as almost no private papers or newspapers for this period are extant, the survival of the records of the assembly and certain urban parishes in Jamaica makes it possible to understand how these processes shaped the patterns of municipal development in a British Atlantic which persisted past 1783 but faced new and unfamiliar urban pressures.

\section{Background}

Liss (eds.), Atlantic Port Cities: economy, culture and society in the Atlantic world, 1650-1850 (Knoxville, 1991) pp. 117-48

${ }^{16}$ Wilma Bailey, 'Kingston, 1692-1843: a colonial city', (Unpublished PhD thesis, University of the West Indies, Mona, 1974), pp. 181-2, 214-17; Wilma Bailey, 'Social control in the pre-Emancipation society of Kingston, Jamaica', Boletín de Estudios Latinoamericanos y del Caribe, 24 (1978) pp. 108-9; Lorna Elaine Simmonds, "That little shadow of prosperity and freedom": urban slave society in Jamaica, 1780-1834', (Unpublished PhD thesis, University of West Indies, Mona, 1997) pp. 72-104. For a representative survey of current work on the 'black urban Atlantic', see Jorge Cañizares-Esguerra, Matt D. Childs, and James Sidbury (eds.), The black urban Atlantic in the age of the slave trade (Philadelphia, 2013)

${ }^{17}$ Trevor G. Burnard and Emma Hart, 'Kingston, Jamaica, and Charleston, South Carolina: a new look at comparative urbanization in plantation colonial British America', Journal of Urban History, 39 (2013) p. 229 and see also Trevor G. Burnard, 'Towns in plantation societies in eighteenth-century British America', Early American Studies, 15 (2017) pp. 835-59; Trevor G. Burnard and John Garrigus, The plantation machine: Atlantic capitalism in French Saint-Domingue and British Jamaica (Philadelphia, PA, 2016) pp. 50-81. For the continuity of the British Atlantic after 1783, see P. J. Marshall, Remaking the British Atlantic: the United States and the British Empire after American Independence (Oxford, 2012) and the essays in Jerry Bannister and Liam Riordan (eds.), The loyal Atlantic: remaking the British Atlantic in the Revolutionary era (Toronto, 2012) 
By virtue of its size Jamaica was by far the most urbanised colony in the British West Indies in the eighteenth century. Most islands had at least one major settlement, such as Bridgetown in Barbados or St John's in Antigua, but Jamaica already had three large urban areas by 1700 , at Spanish Town, the inland political capital, and Kingston and Port Royal, the twin commercial centres on the south coast (Figure 1). ${ }^{18}$ Kingston had about 14,000 people by 1775 and was the fourth or fifth largest settlement in the British Atlantic. The population had grown to 27,000 by 1790 and 36,000 by 1815 , and even second-order settlements in the Jamaican urban hierarchy such as Spanish Town, Savanna-la-Mar, Montego Bay and Falmouth all had around 3,000 people each by 1800 and were equal in size to leading towns of other islands. As in most other territories, only ten percent of Jamaica's population were urbanised, but their sheer size led to large urban concentrations that posed challenges to the urban elites that their counterparts in other islands faced in a far more attenuated form. These were mainly challenges of slavery and race. White settlers were hugely outnumbered by black slaves and by so-called 'free people of colour', even in towns such as Kingston, where a quarter of the inhabitants in 1788 were white. ${ }^{19}$ The problem of controlling this restive and resentful population defined the politics and society of Jamaica and other islands. Violence was ubiquitous, both in the bloody suppression of large-scale rebellions such as the First Maroon War in the 1730s and Tackey's Revolt in 1760 and in the repeated smaller acts of flogging, imprisonment and punishment that occurred on a daily basis across plantations in the island, and was legitimised and regulated by the slave codes produced by each

\footnotetext{
${ }^{18}$ Richard S. Dunn, Sugar and slaves: the rise of the planter class in the English West Indies, 1624-1713 (Chapel Hill, 1972) pp. 106-10, 178-81. For urban areas in the American South, see Joseph A. Ernst and H. Roy Merrens, "“Camden's turrets pierce the skies!": the urban process in the Southern Colonies during the eighteenth century', William and Mary Quarterly, 30 (1973), pp. 549-74.

${ }^{19}$ Bailey, 'Kingston, 1692-1843', pp. 123-54, 170-8, 180, 204-6; Higman, Jamaica, pp. 58-9; Simmonds, “"Little shadow", pp. 120-8, 135-64, 359-452; Welch, Slave society, pp. 1-19; Trevor G. Burnard, 'Kingston, Jamaica: crucible of modernity’, in Jorge Cañizares-Esguerra, Matt Childs, and James Sidbury (eds.), Early Modern Americas: the black urban Atlantic in the age of the slave trade (Philadelphia, 2013) p. 127.
} 
assembly. ${ }^{20}$ However, these codes took the plantation rather than the city or town as their focus, granting planters wide-ranging powers to control and punish their own slaves but saying much less about how slaves were to be regulated in the looser and more complex urban environments. Historians of the American South have argued that by virtue of their social freedoms, economic opportunities and political limitations, the cities were corrosive of the legal, cultural, social and economic boundaries of slavery, and 'they produced conditions which first strained, then undermined, the regime of bondage' ${ }^{21}$ Towns in West Indian islands such as Jamaica faced similar problems, and met them by using their assemblies to adapt familiar metropolitan urban practices to these new conditions.

\section{[Insert Figure 1 here]}

James Robertson, Louis Nelson and others have shown that settlers in Jamaica had already adapted metropolitan urban practices to local conditions, creating 'creole' forms of architecture and urban planning to accommodate the different weather and the earthquakes and hurricanes of the tropics, and creating distinct urban spaces that differed from rural plantations. $^{22}$ By the 1750 s towns were definitely also distinctive economic and social spaces, characterised by unique patterns of commercial activity, landholding and population in which a large number of whites rubbed shoulders with growing communities of Jews and

\footnotetext{
${ }^{20}$ Trevor G. Burnard, Planters, merchants, and slaves: plantation societies in British America, 1650 - 1820 (Chicago, IL, 2015) pp. 55-87; Trevor G. Burnard, Mastery, tyranny, and desire: Thomas Thistlewood and his slaves in the Anglo-Jamaican world (Jamaica, 2004) pp. 146-62, 178-80, 251-5; Diana Paton, No bond but the law: punishment, race, and gender in Jamaican state formation, 1780-1870 (Durham, NC; London, 2004) pp. 19-31; Michael Craton, Testing the chains: resistance to slavery in the British West Indies (Ithaca, NY, 1982) pp. 67-96, 125-38

${ }^{21}$ Richard Clement Wade, Slavery in the cities: the South, 1820-1860 (New York, NY, 1964) pp. 4, 143-242; Dennis Charles Rousey, Policing the southern city: New Orleans, 1805-1889 (Baton Rouge, LA, 1996) pp. 3-8, 12-24. For a comparison with rural conditions, see Sally E. Hadden, Slave patrols: law and violence in Virginia and the Carolinas (Cambridge, MA, 2001).

${ }^{22}$ Louis P. Nelson, Architecture and empire in Jamaica (New Haven, CN, 2016) pp. 10-35, 65-96, 131-217; Robertson, Ancient glory, pp. 37-52, 81-8, 94-129, 137-50; Bailey, 'Social control', pp. 81-94; Matthew Mulcahy, Hurricanes and society in the British Greater Caribbean, 1624-1783 (Baltimore, 2006) pp. 118-36
} 
free people of colour, and urban slaves, who were usually domestic servants or small artisans and traders rather than agricultural labourers. ${ }^{23}$ A brief but intense spat in this decade between planters in Spanish Town and merchants in Kingston over the location of the colonial capital shows that these towns clearly possessed distinct cultural identities that distinguished them from each other and the surrounding countryside. ${ }^{24}$ However, until the 1780s the municipal space did not really exist in Jamaican in a political sense, since there was nothing to distinguish between urban and rural areas of local government. Most large British towns were governed by municipal corporations or commissions, mirrored in North America by the incorporation of towns such as New York and Philadelphia, while in South Carolina the governance of Charleston was divided after 1732 between the vestry of the parish and the statutory commission noted above. ${ }^{25}$ By contrast, towns in Jamaica, the West Indies and most of the plantation colonies except South Carolina were unincorporated and - perhaps deliberately - were ruled by the same vestries which administered the surrounding rural parishes. ${ }^{26}$ Except in Bridgetown and Kingston, where the parish was roughly co-extensive with the town itself, even major urban areas such as Spanish Town were thus merely parts of large rural parishes. ${ }^{27}$ Until the 1780 s there were no distinctive structures for municipal

\footnotetext{
${ }^{23}$ Bailey, 'Kingston, 1692-1843', pp. 105-42, 155-78; Greene, Settler Jamaica, pp. 110-76; Higman, 'Jamaica port towns', pp. 117-48; Burnard, “'Grand Mart of the Island”, pp. 225-41; Burnard, 'Kingston', pp. 122-44; Robertson, Ancient glory, pp. 56-79

${ }^{24}$ Jack P. Greene, "'Of liberty and the colonies": a case-study of constitutional conflict in the mid-eighteenth century British American empire', in David Womersley (ed.), Liberty and American experience in the eighteenth century (Indianapolis, IN, 2006) pp. 62-80; George Metcalf, Royal government and political conflict in Jamaica, 1729-1783 (London, 1965) pp. 121-37, 141-4; Robertson, Ancient glory, pp. 54-5, 89-102 ${ }^{25}$ Carl Bridenbaugh, Cities in the wilderness: the first century of urban life in America, 1625-1742 (New York, NY, 1955) pp. 6-8, 144-6, 304-5; Carl Bridenbaugh, Cities in revolt: urban life in America, 1743-1776 (New York, NY, 1955) pp. 6-11, 217-24; Jessica C. Roney, Governed by a spirit of opposition: the origins of American political practice in colonial Philadelphia (Baltimore, MD, 2014) pp. 38-58; Hart, 'City government', pp. 195-211. For Britain, see Sweet, English town, pp. 27-40; Hill, 'Dublin government', pp. 149-65 ${ }^{26}$ Kamau Brathwaite, The development of creole society in Jamaica, 1770-1820 (Oxford, 1971) pp. 19-22; Christer Petley, Slaveholders in Jamaica: colonial society and culture during the era of abolition (London, 2009) pp. 55, 60-1. For the exception that proves the rule, an urban borough deliberately created by planters in order to isolate and contain the power of urban elites, see Paul Musselwhite, "TThis infant borough": the corporate political identity of eighteenth-century Norfolk', Early American Studies, 15 (2017) pp. 801-34 ${ }^{27}$ Robertson, Ancient glory, pp. 65-79, 81-119, 123-9, 142-50; Welch, Slave society, pp. 108-19.
} 
government in Jamaica, or even, arguably, a sense that urban areas might have problems of social and economic control different from rural areas that required distinctive solutions.

During this period legislative intervention therefore tended to be piecemeal and ad hoc, despite the rapid increase in the output and efficiency of the house of assembly in this period, and only 1769 did the outlines of an specifically 'urban' legislative policy even begin to emerge. $^{28}$ The vestry of Kingston spent $£ 30$ securing an act for the construction of a fish market, '[as] there is no fixed place ... for the sale of fresh fish, and it is become highly necessary that a proper house or market-house be erected or the convenience of sellers as well as the buyers of fresh fish ... and for the better exposing such fresh fish to sale'. Tacked on to the end of the act were a series of miscellaneous clauses which incorporated the churchwardens of the parish as a body corporate for better recovery at law of parochial taxes; permitted them to levy a parochial tax to pay for scavengers to keep the streets clean; revived an earlier act allowing the vestry to regulate the beef market; and authorised the prosecution of all persons leaving obstructions such as timber, horses or carts in the street. ${ }^{29}$ After the smaller town of Savanna-la-Mar was destroyed by a combination of fires, hurricanes and flooding in 1779 and 1780, an act was passed appointing trustees to survey and buy nearby land, to lay out 'new streets, squares, avenues, lanes and alleys ... as may prove conducive to the security of the said town and to the health of the inhabitants thereof', with a market and court-house, and to cut an aqueduct for the supply of water and a canal for access to the harbour. ${ }^{30}$ Although the act included several additional measures allowing the trustees to tear down illegal huts and hovels that 'endanger[ed] the security of the town or the health of the inhabitants', to buy fire engines and buckets, to regulate the market, and even to ban

\footnotetext{
${ }^{28}$ For the efficiency of the assembly, see Graham, 'Jamaican legislation', pp. 327-55

${ }^{29}$ The Laws of Jamaica (7 vols., St Jago de la Vega, Jamaica, 1802-24) vol. ii, 83-7; JA, 2/6/5 f. 66r,

${ }^{30}$ Acts of assembly passed in the island of Jamaica, from 1770 to 1783, inclusive (Kingston, Jamaica, 1786) pp. 213-15
} 
inoculation taking place in the town, 'for the better security and preservation of the lives and health of His Majesty's subjects', suggesting a recognition some of the distinctively urban issues faced by the town, it failed to cover a number of other areas of urban activity which would feature in later acts. Colonial legislation was therefore already being used for piecemeal urban improvement in Jamaica, as in England and elsewhere, but not to offer comprehensive legislative solutions to common municipal problems. ${ }^{31}$

The need for such a solution crystallised though in the 1780s, a moment of unchecked insecurity. Wartime conditions had cut off imports of provisions and raised fears on the plantations about slave revolt, while in Kingston itself an influx of white Loyalist refugees and slaves, as well as British soldiers and sailors and French and Spanish prisoners, had increased the size of the town by at least half and had overwhelmed the existing measures for controlling urban society. ${ }^{32}$ The expansion of policing powers was therefore a reflection of the insecurity created by white as well as black disorder, challenging an important strand in recent work which has stressed the close solidarity of whites within slave societies. George Frederickson introduced the concept of the 'herrenvolk democracy' in the American South, in which the exclusion of blacks and the egalitarian enfranchisement of whites were two sides of the same coin, and this has been applied to the West Indies by Trevor Burnard and others to show how even middling and poor whites could be part of this classless racial community. ${ }^{33}$ Yet a focus on urban management serves as a reminder that a strict social hierarchy also existed in Jamaica, in which elites feared the potential for disorder among the poorer whites,

\footnotetext{
${ }^{31}$ Though see Robertson, Ancient glory, pp. 81-7, 95-118

${ }^{32}$ Bailey, 'Kingston, 1692-1843', pp. 181-5; Simmonds, “Little shadow”, p. 62. For the wider context, see Andrew O'Shaughnessy, An empire divided: the American Revolution and the British Caribbean (Philadelphia, 2000) pp. 167-81, 199; Selwyn H.H. Carrington, 'The American Revolution and the British West Indies economy’, Journal of Interdisciplinary History, 17 (1987) pp. 823-50

${ }^{33}$ Burnard, Mastery, tyranny and desire, pp. 70-100, 151-2; Burnard, Planters, merchants and slaves, pp. 87-97; Brathwaite, Creole society, pp. 135-50, 266-305; David Lambert, White creole culture, politics and identity during the age of abolition (Cambridge, 2005) pp. 73-104; Petley, Slaveholders in Jamaica, pp. 53-60, 62-3
} 
especially rootless soldiers and sailors who lived outside the social structures of family and patronage. ${ }^{34}$ Episodes such as the Impressment Riots in Boston in 1747 showed how white groups had the potential to threaten public order. 'The solidarity that tended to bind white men in slave society was therefore not all-encompassing', Christer Petley has concluded, 'and when those from outside the elite felt that their political leaders were asking too much of them, they could react angrily'. ${ }^{35}$ Kingston therefore feared a combination of black revolt and white disorder which was specific to the urban environment and required not only specific measures for law enforcement but also a wider package of 'police' powers to manage this fragile urban society.

Such problems had hitherto been addressed intermittently. ${ }^{36}$ During the First Maroon War in the 1730 s the vestry had secured an act which permitted them to raise $£ 500$ per year to maintain a salaried night watch, with additional measures to prevent fire hazards and dig three wells with pumps. ${ }^{37}$ A bill was brought forward in 1759, during the Seven Years War, to expand the watch and to light the streets, but failed to pass. ${ }^{38}$ As Diana Paton has shown, the expansion of workhouses and prisons in the island for the better control of the slave population began in 1777 with an act for the Kingston workhouse, which was then expanded in 1780 into a permissive measures giving the other, rural, parishes in the island similar

\footnotetext{
${ }^{34}$ See in particular Cecilia Green, 'Hierarchies of whiteness in the geographies of empire: Thomas Thistlewood and the Barrets of Jamaica', Nieuwe West-Indische Gids / New West Indian Guide, 80 (2008) pp. 5-43. For the experience of soldiers and sailors in West Indian societies, see Roger N. Buckley, The British Army in the West Indies: society and the military in the revolutionary age (Gainesville, FL, 1998) pp. 173, 190, 327-33; Nicholas Rogers, The press gang: naval impressment and its opponents in Georgian Britain (London, 2007) pp. 88-103; Christopher P. Magra, 'Anti-impressment riots and the origins of the American Revolution', International Review of Social History, 58 (2013) pp. 131-51; Petley, Slaveholders in Jamaica, pp. 64-5

${ }^{35}$ Petley, Slaveholders in Jamaica, p. 64. For other limitations to white solidarity, see Gad J. Heuman, Between Black and White: race, politics, and the free coloreds in Jamaica, 1792-1865 (Westport, Conn, 1981) pp. 4-10, 23-8; Brathwaite, Creole society, pp. 168-74; James Robertson, 'A 1748 "Petition of Negro Slaves" and the local politics of slavery in Jamaica', William and Mary Quarterly, 67 (2010) pp. 319-42; Daniel Livesay, Children of uncertain fortune: mixed-race Jamaicans in Britain and the Atlantic family, 1733-1833 (Chapel Hill, NC, 2018) pp. 20-59

${ }^{36}$ For context see Bailey, 'Kingston, 1692-1843', pp. 178-82.

${ }^{37}$ Acts of assembly passed in the island of Jamaica, from 1681 to 1737 inclusive (London, 1738) pp. 255-7.

${ }^{38}$ Journals of the House of Assembly of Jamaica (14 vols., Kingston, Jamaica, 1808-26) vol. v, 125, 133
} 
powers. ${ }^{39}$ Kingston had therefore tackled the problem the same way as Boston, Philadelphia and New York, which had all created night watches in a piecemeal fashion as the need arose, as had towns and cities in Britain. ${ }^{40}$ By 1781 it was paying ten watchmen to patrol the streets and arrest sailors, slaves, and 'negroes and mulattoes ... who shall be found drinking in punch shops', reflecting a real concern at the risks of disorder and damage. ${ }^{41}$ In October however the vestry represented to the assembly their concerns at 'the great defect of the police of the said parish, especially with regard to fires, the nightly watch and rum shops', therefore using the term to encompass a range of urban issues which required stronger municipal powers. The act they secured duly gave the vestry expansive powers not just to maintain a larger night watch but also to prevent fire, set the assize of bread, license rumshops, detect and destroy putrid provisions. ${ }^{42}$ From January 1782 the vestry also became concerned about 'the designs of some wicked persons who have attempted and may again attempt to set it on fire', largely French and Spanish prisoners of war in the town, and secured an act in December 1784 which reformed the old Night Watch as a new Town Guard under closer parochial control. ${ }^{43}$

\section{[insert Figure 2 here]}

The acts of 1781 and 1784 were therefore landmarks in legislation, consolidating a raft of separate measures into two statutes specifically intended to address a series of interconnected urban problems, and providing a model for other towns who felt that they faced similar

\footnotetext{
${ }^{39}$ Paton, No bond, pp. 19-31

${ }^{40}$ Bridenbaugh, Cities in the wilderness, pp. 63-78, 215-31, 374-91; Bridenbaugh, Cities in revolt, pp. 108-22, 297-305. For Britain, see Ruth Paley, “'An imperfect, inadequate and wretched system”? Policing London before Peel', Criminal Justice History, 10 (1989) pp. 95-130; Elaine A. Reynolds, Before the bobbies: the night watch and police reform in metropolitan London, 1720-1830 (Basingstoke, 1998); Barrie, Police development, pp. 1-49, 92-114, 146-63

${ }^{41} \mathrm{JA}, 2 / 6 / 6,11$ Jan 1781.

${ }^{42}$ Laws of Jamaica, 1770-83, pp. 280-90; JA, 2/6/6, 11/10/1781; JA, 2/6/6, 7/1/1782

${ }^{43}$ JA, 2/6/6, 10/1/1782, 17/1/1782, 14/7/1783; The Laws of Jamaica, vol. ii, 349-52
} 
issues. In December 1787 the vestry of St Catherine's in Spanish Town accordingly sought an act 'for the better regulating the police within the town', the first time the term featured in the title of an act, which brought together existing powers from an act of 1770 and added others, based on the Kingston acts, for liquor licensing, fire prevention, slave curfews, traffic offences and the repair and cleansing of the streets. ${ }^{44}$ The vestry of St James' made a similar bid in November 1788, stating that 'from want of a regular and established police in the parish', especially the town of Montego Bay, they faced 'great inconvenience' from fire, traffic, tippling and riots. ${ }^{45}$ The term 'police' had by 1788 therefore become distinctively associated, as in Scotland, with the control of urban problems. This may be because there was a strong Scottish presence in Jamaica, and long-standing connections with Glasgow, where an Inspector of Police had been briefly created in 1779, but Barrie has shown that the term was not used in Glasgow in its wider sense until the failed police bill of $1783 .{ }^{46}$ Jamaican elites may therefore have adopted the term independently, or, more likely, copied it from the 'boards of police' set up in New York, Philadelphia, Charleston and Savannah when these cities were occupied by British forces. ${ }^{47}$ The superintendents of each board were given extensive powers to regulate the economy and society of these towns as well as to maintain public order; the Superintendent of Police in New York, for example, was empowered to issue regulations 'tending to the suppression of vice and licentiousness, the support of the poor, the direction of the nightly watch, the regulation of markets and ferries, and all other

\footnotetext{
${ }^{44}$ The Laws of Jamaica, vol. ii, 92-6, 379-90

45 Journals, vol. iii, 444

${ }^{46}$ Alan L. Karras, Sojourners in the sun: Scottish migrants in Jamaica and the Chesapeake, 1740-1800 (Ithaca, NY, 1992) pp. 46-80, 118-69; Douglas Hamilton, Scotland, the Caribbean and the Atlantic world, 1750-1820 (Manchester, 2005) pp. 55-107; Barrie, Police development, pp. 61-74

${ }^{47}$ John M. Coleman, 'Joseph Galloway and the British occupation of Philadelphia', Pennsylvania History, 30 (1963) pp. 272-300; Daniel Joseph Hulsebosch, Constituting empire: New York and the transformation of constitutionalism in the Atlantic world, 1664-1830 (Chapel Hill, NC, 2005) pp. 161-3; Ruma Chopra, Unnatural rebellion: loyalists in New York City during the Revolution (Charlottesville, 2011) pp. 148-52; Donald F. Johnson, 'The failure of restored British rule in Revolutionary Charleston, South Carolina', Journal of Imperial and Commonwealth History, 42 (2014) pp. 22-40
} 
matters in which the economy, peace and good order of the city ... are concerned' ${ }^{48}$ The 'police' acts of Jamaica therefore emerged from a specifically urban milieu in the British Atlantic, to meet similar issues and to hold it together at a moment when it seemed on the verge of being torn apart.

The existing police acts also therefore provided by 1784 a model set of urban powers that could then be revived to maintain the unity of the post-Revolutionary British Atlantic as further threats emerged after 1791. The overthrow of the planter regime within the neighbouring colony of St Domingue during the Haitian Revolution by an uprising of free and enslaved people of colour was a transformative moment for the elites of Jamaica, especially as this revolutionary example spread to other French colonies such as Guadeloupe and Martinique and destabilised nearby territories such as Santo Domingo, Cuba and Grenada. ${ }^{49}$ Not only did Jamaican planters fear the spread of revolutionary ideology that might encourage a similar rebellion locally, but these events generated several waves of French and Spanish refugees who arrived in the island with their slaves. ${ }^{50}$ Although in many cases the planters were royalists who supported Britain after it entered the war with France in 1793, they were an alien and highly visible element, concentrated in Kingston and other towns, where they rubbed shoulders with the same crowds of French and Spanish prisoners of war and unruly groups of British soldiers and sailors which had worried urban rulers in 1780 . The Second Maroon War in 1795 was both triggered by this heavy-handed paranoia and served to reinforce fears among whites about the real loyalties of free and enslaved persons of

\footnotetext{
${ }^{48}$ John Austin Stevens (ed.), Colonial Records of the New York Chamber of Commerce, 1768-1784 (New York, NY, 1867) p. 343.

${ }^{49}$ Craton, Testing the chains, pp. 180-210, 224-38; David Geggus, 'Jamaica and the Saint Domingue slave revolt, 1791-1793', The Americas, 38 (1981) pp. 219-33

50 Simmonds, “'Little shadow"', pp. 62-5; Bailey, 'Kingston, 1692-1843', pp. 206-9, 214-17; Jacques de Cauna, 'La diaspora des colons de Saint-Domingue et le monde créole: le cas de la Jamaïque', Outre-Mers: Revue d'histoire, 304 (1994) pp. 333-59
} 
colour in Jamaica. ${ }^{51}$ The vestry of Kingston received a petition in March 1798, for instance, that 'there are an extraordinary number of prisoners of war and strangers of various descriptions at large ... in so much as to occasion alarm among the inhabitants thereof', and another in May 1799 'of a large assemblage of negroes and other disorderly persons ... armed with sticks and clubs, which, with drums and other noisy instruments, greatly disturbed the peace of that part of the town and endangered the lives of the inhabitants thereof'.52

Between 1794 and 1806 a number of towns therefore felt the need to secure new or more expansive police powers to address these renewed problems of urban security and safety. The vestry of Kingston obtained a further act in December 1794 which increased its powers to regulate the watch and a range of other services. ${ }^{53}$ The towns of Montego Bay and Falmouth in the north-eastern part of the island had expanded enormously since the 1770s and now had several thousand inhabitants, and the parish vestries successfully obtained bills 'to regulate the police thereof'. ${ }^{4}$ The petition from Montego Bay, for instance, stated that the town had increased in size but they were still 'unnecessarily exposed to great danger, by the want of legal provisions for regulating the police of the said town, particularly respecting public markets and a nightly watch for the prevention and extinguishing of fires', and the preamble of the police act duly noted that it was for the security of the town from fire. ${ }^{55}$ The suburban parish of St Andrew put forward their request in 1797 for 'a proper police' in the area next to Kingston, for addressing theft and the risk of fire, but the bill was opposed by the

\footnotetext{
${ }^{51}$ Craton, Testing the chains, pp. 211-23; David Geggus, 'The enigma of Jamaica in the 1790s: new light on the causes of slave rebellions', William and Mary Quarterly, 44 (1987) pp. 274-91

52 JA, 2/6/7 f. $81 \mathrm{v}, 112 \mathrm{v}$

${ }^{53}$ The Laws of Jamaica, vol. iii, 46-58. See also Simmonds, "Little shadow", (Unpublished "Little shadow" pp. 98-9.

${ }^{54}$ Higman, 'Jamaica port towns', pp. 117-48; Nadine Hunt, 'Expanding the frontiers of western Jamaica through minor Atlantic ports in the eighteenth century', Canadian Journal of History, 45 (2010) pp. 485-502

55 Journals, vol. ix, 306
} 
Kingston vestry, who contended that these areas were already 'subject to the police' of the town and that this act would undermine their efforts. ${ }^{56}$ In 1800 the town of Port Royal secured its police act by pointing to its increased size and the problems and dangers the residents faced 'by the want of legal provisions for regulating the police of the said town, particularly respecting public markets, a nightly watch for the prevention and extinguishing of fires, and the want of proper regulation for ... wherries and other craft'. ${ }^{57}$ Spanish Town obtained an expansion of its police act in 1802 which granted additional powers, and a further act was passed for the town of St Ann on the northern coast in 1805, on the basis, according to its preamble, that the town was now a major port 'and ought to be governed by a regular police'. ${ }^{58}$ Only Savanna-la-Mar did not secure legislation granting police powers. Under the renewed fears of violent disorder, Jamaican towns asserted their identity as distinct urban environments which needed a full range of 'police' powers for their wider security.

This can be seen most clearly in the case of Kingston. By April 1795 the town had its own Inspector of Police, whose duties included overseeing the cleaning of streets and maintaining cart and dray licenses. ${ }^{59}$ Indeed, the vestry noted in January 1798 that combining the posts of Police Officer and scavenger would probably help enforce the police law. ${ }^{60}$ A continued sense of insecurity led the vestry to secure a further act in 1801 which incorporated it as the 'Corporation of Kingston' and converted it into a recognisably English municipal corporation, complete with a mayor, aldermen and common council. ${ }^{61}$ The reasons given by the vestry for seeking this comprehensive remodelling of their municipal government were that the continued influx of aliens had exposed the inadequacy of existing police laws for the

\footnotetext{
${ }^{56}$ Ibid., vol. x, 44, 46; JA, 2/6/7 f. 68v

${ }^{57}$ Ibid., vol. x, 494; The Laws of Jamaica, vol. iv, 105-20

58 The Laws of Jamaica, vol. iv, 213-29; vol. v, 48-61

${ }^{59} \mathrm{JA}, 2 / 6 / 7$ f. $5 \mathrm{r}, 42 \mathrm{v}, 63 \mathrm{v}$.

${ }^{60} \mathrm{JA}, 2 / 6 / 7 \mathrm{f}$. $76 \mathrm{r}$. The Scavenger was charged with the cleaning and repair of the streets.

${ }^{61}$ The Laws of Jamaica, vol. iii, 144-60
} 
safety of the town, making it 'absolutely necessary that provision should be made for establishing, maintaining and enforcing an efficient and strict police, to be regulated in detail and fitted to the present situation of things' ${ }^{62}$ The act formalised the post of Police Officer and listed his duties as the preservation of law and order, the leadership (as Head Constable) of the Town Guard, and the presentation for prosecution before the magistrates of the city of 'all offenders against all or any of the public laws in any wise touching or concerning the order, government and police of the said city and parish'. The vestry minutes show that in practice his duties were much broader. He was instructed at various points to apprehend all seamen and any French prisoners found wandering around the city and to update the lists of French slaves owned by residents, but also to inspect local bakehouses at least twice a week to enforce the assize of bread; to order butchers to prevent their slaves cracking whips when driving cattle through the city; to take down a piazza on Upper King Street which constituted a nuisance to traffic; and to inspect the prison graveyard to check for abuses. ${ }^{63}$ The Scottish understanding of policing as a comprehensive exercise to address the social causes of urban disorder was therefore mirrored or imitated in Kingston, the act itself repeatedly stating that all these measures were 'for the good government and police of the said city'. ${ }^{64}$

\section{Contents}

However, while both Scottish and Jamaican towns by the 1790s increasingly saw a comprehensive 'police' act as the best solution to problems of urban disorder, this did not mean that there was much overlap in the actual measures included in these acts.

\footnotetext{
62 Journals, vol. x, 507, 517

${ }^{63}$ JA, $2 / 6 / 8$ f. 79, 99-100, 114-15, 144, 156, 158-9 and 1/2/1808, 11/7/1808, 18/7/1808

${ }^{64}$ The Laws of Jamaica, vol. iv, 151, 153, 154, 159
} 
Jamaican legislation, as in Charleston, reflected the particular needs of towns within a tropical colony dominated by plantation slavery and exposed even more directly than Scottish towns to the problems of foreign refugees and prisoners of war. ${ }^{65}$ All police acts in included unique provisions specific to individual towns. For example, the Montego Bay act of 1794 empowered the town to raise taxes to drain the local swamp for the purposes of public health, to remove 'the evil effects from noxious vapour', while the Falmouth act allowed the vestry to purchase and expropriate land for the construction of an aqueduct. The Port Royal act included clauses for the registration and licensing of wherries, canoes and boats in Kingston harbour. ${ }^{66}$ However, the police acts also included many common elements, including fire prevention, liquor licensing, traffic controls, street cleaning and repair, market regulation, public order and, crucially, measures for incorporation. Like the Scottish police acts, many also made provision for greater powers of taxation to help support this new municipal infrastructure. ${ }^{67}$ But whereas Scottish and English acts also frequently reflected an underlying determination to encourage popular involvement and elevate the middling sort into active and engaged urban citizens, in Jamaica the exclusion of foreigners, Jews and free and enslaved people of colour from political participation meant that the police acts served to emphasise hierarchy, security and social control, and thus more closely resembled the oligarchic 'select' vestries of eighteenth century England.

Every police act included measures for a night watch, either updating the existing provisions in the case of Kingston and Spanish Town or creating it from scratch in other towns. ${ }^{68}$ Vestries were empowered to appoint a number of constables to patrol the streets, to establish a guard house for the reception of persons arrested, and to publish regulations for the conduct

\footnotetext{
${ }^{65} \mathrm{JA}, 1 \mathrm{~B} / 5 / 14 / 2$ f. 136r-137r. For Colquhoun, see Barrie, Police development, pp. 74-7

${ }^{66} \mathrm{JA}, 2 / 19 / 3,4 / 7 / 1801$

${ }^{67}$ Barrie, Police development, pp. 24, 37-8, 61-6, 110-12

${ }^{68}$ The Laws of Jamaica, vol. iii, 111-14, 231-6; vol. iv, 105-7, 153
} 
and guidance of the watch. They were instructed to 'use their utmost endeavours to prevent all mischiefs happening by fire and all murders, burglaries, robberies and breaches of the king's peace, riots and all other outrages and disorders, and all tumultuous assemblies of slaves', and were given authority thereby to detain those detected in commission of these crimes or in the streets after curfew and commit them to the watch-house. The Spanish Town police act of 1787 complained that slaves were permitted to move about the town at night, 'to the great annoyance of the inhabitants and injury of the health of the said slaves', and most police acts established a curfew from 9pm to $5 \mathrm{am}$ and empowered the watch to arrest and incarcerate in the workhouse any slaves found in the streets during these hours without a ticket of leave from their masters. ${ }^{69}$ A concern with surveillance, public order, security and the control of threatening persons therefore dominated many police acts, mirroring a shift in English and Scottish towns towards more professional constabularies or the 'new police', and complementing the broader move within Jamaica towards new structures of control such as the workhouse and prison, as described by Diana Paton. However, it was not necessarily vital to them, as the first police act for Falmouth in 1794 did not have any provisions for a night watch, which was instead created by an supplementary police act in 1795, suggesting that these acts had broken free of their origins in security and had instead become, as in Scotland, a more generic series of powers open to urban magistrates. ${ }^{70}$

As will have become clear, fire was also a major concern for towns across Jamaica. Indeed, both the 1781 act for Kingston and its amending act in 1799 were usually referred to in the vestry minutes as fire acts, and the latter was prompted by a report to the vestry in November

\footnotetext{
${ }^{69}$ Ibid., vol. ii, 386; vol. iii, 108, 114, 234; vol. iv, 106

70 The Laws of Jamaica, vol. iii, 231-6. Measures for a watch were also missing from the police act for St Ann in 1805: The Laws of Jamaica, vol. v, 48-61
} 
1799 on the dangers created by loopholes in previous acts. ${ }^{71}$ Police acts therefore always included a raft of measures intended particularly for urban fires, along the same lines as similar measures in Britain and North America but adapted to local conditions and resources. ${ }^{72}$ Householders were required to maintain one or more fire buckets, marked with their name and kept in good repair, and supply a fixed number of slaves to assist in extinguishing fires whenever necessary. Vestries were instructed to purchase and maintain fire engines with leather pipes and sockets, and fire-hooks for pulling down buildings; to employ captains and crews; and to offer rewards both to free people and slaves who assisted in fighting fires. Firewardens were to be elected annually and to carry a white staff as a symbol of their authority. Besides inspecting fire engines and fire buckets regularly, they had sweeping powers to direct crews, volunteers, householders and even the militia and military and naval parties in fighting fires or demolishing houses to make firebreaks, and enjoyed full legal indemnification for all their actions. Certain occupations were put under strict regulation by the acts due to the fire risks they posed. 'There are great numbers of coopers' shops in the said town', stated the Montego Bay police act, for instance, 'the occupiers of which do not take proper care in using fire for burning of casks, whence great mischief may ensue', and the act therefore ordered that fires could only be lit in yards with brick walls eight feet high. ${ }^{73}$ Since fire engines were useless without a supply of water, many acts included additional clauses permitting the vestry to levy taxes for the construction of wells or pumps to be used in extinguishing fires. Almost all also contained measures for licensing tipplinghouses, for the purposes of public safety as well as for public order: the police act for Port

\footnotetext{
${ }^{71}$ The Laws of Jamaica, vol. iv, 17-22; JA, 2/6/6, 12/11/1781, 24/11/1781, 28/11/1785; JA, 2/6/7 f. 118v-119r, $126 \mathrm{v}, 127 \mathrm{v}$.

${ }^{72}$ Bridenbaugh, Cities in the wilderness, pp. 55-63, 206-13, 364-72; Bridenbaugh, Cities in revolt, pp. 98-105; The Laws of Jamaica, vol. ii, 382-6; vol. iii, 102-8, 110-14; vol. iv, 112-15, 213-18; vol. v, 48-54. See also below p. 27.

${ }^{73}$ The Laws of Jamaica, vol. iii, 108
} 
Royal stated that it would 'greatly tend to the security of the said town ... from accident and dangers of fire' ${ }^{74}$

These measures meshed with a wider concern for the urban environment in Jamaican police acts, and were complemented by other powers for addressing the interrelated issues of public health, sanitation, consumer protection and traffic. The acts allowed vestries to use slaves in the workhouse to clean and repair streets, to remove rubbish and filth for disposal and to cut and clear drains to remove surplus water, or to levy a tax for hiring scavengers to carry out all these jobs. ${ }^{75}$ Most noted that the health of the inhabitants 'hath been greatly endangered by means of putrid saltfish and other provisions, rancid butter, oil and other offensive commodities having been from time to time exposed', and gave vestries the power to inspect, confiscate and destroy these provisions, and also to ban hawkers and pedlars and restrict retailing to the markets, where municipal authorities could exercise closer control. ${ }^{76}$ Though an act was passed in 1794 allowing parish vestries across the island to regulate the price and assize of bread, these measures were generally replicated in municipal police acts. Bakers were required to mark their initials on the bread to help trace lightweight or contaminated bread back to its source, and constables were sometimes given powers to inspect bake-houses monthly in order to detect such frauds. The Falmouth police act also empowered the vestry to ascertain and fix the assize and weight of grass sold in the town for the horses and other livestock. All acts had clauses empowering constables to arrest slaves 'found riding or driving furiously or immoderately through the streets or lanes of the said town ... or who

\footnotetext{
${ }^{74}$ Ibid., vol. ii, 379-81; vol. iii, 100-2, 126-7; vol. iv, 111, 220. See also Bridenbaugh, Cities in the wilderness, pp. 110-15

${ }^{75}$ The Laws of Jamaica, vol. ii, 387-8; vol. iii, 49-50, 114-15, 124-5; vol. iv, 107-9, 119; vol. v, 55-6

${ }^{76}$ Ibid., vols. ii, 388; vol. iii, 50, 56-7, 116-17, 125, 236-8; vol. iv, 110-19, 223-5; vol. v, 57-9. For urban hawking and peddling, see Sidney W. Mintz, 'The origins of the Jamaican internal marketing system', Yale University Publications in Anthropology, 57 (1960) pp. 1-26; Lorna Elaine Simmonds, 'The Afro-Jamaican and the internal marketing system: Kingston, 1780-1834', in Kathleen Monteith and Glen Richards (eds.), Jamaica in slavery and freedom: history, heritage and culture (Kingston, 2002) pp. 274-90
} 
shall wilfully or carelessly turn any horse, mare, gelding, mule or ass loose', while several allowed vestries to order the trapping and destruction of stray animals, and the Kingston police act of 1794 had further clauses for licensing and regulating drays within the town, a provision which the Police Officer was ordered to enforce in $1797 .{ }^{77}$ All these provisions had little to do with law and order, but were common urban problems that had similar solutions and had hitherto been addressed both in Jamaica and elsewhere in a piecemeal way. ${ }^{78}$

This growing sense of urban identity in the 1790s was both reflected and probably enhanced by the new practice of incorporating these urban areas. As noted above, only in Kingston did jurisdictional and urban boundaries overlap, and municipal governance was therefore carried out by rural vestries and their magistrates. From an early period though the assembly had also incorporated councilmen, assemblymen, magistrates and vestrymen as commissioners for the exercise of certain public roles, such as the government of the complex at the hot springs at the Bath in 1690 or the maintenance of the highway and ferry between Spanish Town and Kingston in the 1760 s. $^{79}$ Resembling the statutory commissions created in England, as well as in Charleston and Philadelphia, they were primarily a legal convenience, since their common seal and perpetual succession meant that public business could be done by commissioners interchangeably rather than in their individual capacities, while the practice of appointing commissioners from multiple vestries facilitated the care of turnpikes, bridges, roads and ferries which crossed parishes. Commissions were set up in parishes and made bodies corporate for the purpose of recovering tax arrears, organising the sale and purchase of lands, managing trusts and bequests, and various other temporary and specific

\footnotetext{
77 The Laws of Jamaica, vol. ii, 388-9; vol. iii, 52-3, 57, 109-10, 125-6, 238; vol. iv, 108, 111, 221-3; JA, 2/6/7 f. $63 \mathrm{v}$

${ }^{78}$ Bridenbaugh, Cities in the wilderness, pp. 12-22, 26-9, 152-70, 192-5, 313-25; Bridenbaugh, Cities in revolt, pp. 28-36, 235-45, 277-80

${ }^{79}$ For a contemporary summary of the powers and development of such corporations, see John Lunan, The Jamaica magistrate's and vestryman's assistant (St Jago de la Vega, 1828) pp. 15-16, 67-9, 127-8
} 
purposes. ${ }^{80}$ However, in 1792 the churchwardens of St James secured an act for managing parish lands which incidentally but deliberately incorporated them as a body politic and corporate '[with] full power and authority in all parochial matters whatsoever, as well in the several matters and things touching and concerning the general or collective interest or affairs of the inhabitants of the said parish' ${ }^{81}$ The police acts which were then passed in the $1790 \mathrm{~s}$ included similar measures, the act for Spanish Town in 1802, for example, incorporating a quorum of magistrates and vestrymen as 'The Justices and Vestry of St Catherine' for 'mak[ing] alterations and improvements in the said town ... and for the better carrying this act into execution'. ${ }^{82}$ Since urban vestryman would tend to dominate such commissions by virtue of their residence, this essentially created municipal corporations for these towns, a process which peaked in 1801 with the full municipal incorporation of Kingston 'for better ordering and managing the police of the town and parish'. ${ }^{83}$

In Jamaica, as in Scotland, towns therefore used the colonial legislature to obtain comprehensive police acts which allowed them to more conveniently and effectively discharge routine municipal business. Vestries clearly imitated each other, with groups of clauses often copied verbatim from one act to another but re-ordered, edited and supplemented as local circumstances dictated. Major or substantive changes were still done through separate legislation. For example, after Montego Bay experienced a major fire in 1795 the powers for preventing further conflagrations were included in the police act noted earlier, but the powers for rebuilding the town were granted in a separate bill passed in May 1796 and resembling the earlier one passed for Savanna-la-Mar in 1780. 'By reason of the crowding together a number of buildings without sufficient lanes and alleys to separate and

\footnotetext{
${ }^{80}$ The Laws of Jamaica, vol. ii, 84-5, 94, 455-6

${ }^{81}$ Ibid., vol. iii, 17-19

${ }^{82}$ Ibid., vol. iv, 226-7

${ }^{83}$ Ibid., vol. iv, 144-60
} 
afford passages between them, and also from the avenues, streets, lanes and alleys of the said town being in many cases narrow, crooked and ill-contrived', the bill stated, 'the flames spread with great rapidity, so that great part of the town now remains in ruins' ${ }^{84}$ To prevent this the town would therefore be rebuilt on a new grid with wider and straighter streets, overseen by trustees separately incorporated as 'The Corporation of Montego Bay and St James'. They had powers to survey and applot new streets and properties, to sell or lease them as necessary, to borrow up to $£ 6,000$ by issuing municipal bonds for this purpose, to raise $£ 10,000$ for the construction of new public buildings, and to make and enforce building codes, 'so that the same shall not intrude on or recede from the boundary or line of the streets and passages'. The town also secured a separate act chartering a joint stock company, the first one incorporated in the British West Indies, for the construction of a 'close harbour' to protect shipping, while Falmouth set up its own company in 1799 for constructing waterworks after the aqueduct authorised by the police act of 1795 failed to work. ${ }^{85}$ The police acts were therefore just one element, albeit an important one, in a growing resort to colonial legislation in this period by Jamaican urban interest groups described earlier in this article.

However, while Jamaica mirrored certain aspects of the Scottish experience, the acts themselves reflected not only local challenges but also the particular nature of society in a plantation colony shaped by racialised hierarchies. As noted above, in England and Scotland the statutory and police commissions had an underlying expectation that they would encourage civic participation, while Hart has argued that the municipal commission in Charleston embodied similar ideals and was one of many associational structures which

\footnotetext{
${ }^{84}$ Ibid., vol. iii, 169-82

${ }^{85}$ Ibid., vol. iii, 81-100, 127-8; vol. iv, 28-39; Aaron Graham, 'Technology, slavery and the Falmouth Water Company of Jamaica, 1799-1805', Slavery \& Abolition, 39 (2018) pp. 315-32
} 
helped prepare white Americans for active political citizenship after 1783. In the Thirteen Colonies municipal offices were generally part, as in England and Scotland, of the 'unacknowledged republic' of amateur office-holding which enfranchised citizens by giving them both the power and responsibility to work actively for the public good. The fire companies created by the urban legislation or set up spontaneously by volunteers in American town before 1775, for example, were 'part of a loose but organised alliance of civic-minded men from all ranks ... intimately concerned with "duty" and "public spirit", and key vehicles for political participation. ${ }^{86}$ In Jamaica, however, urban whites were in a greater minority even than in Charleston and South Carolina, and the intense paranoia and insecurity which prompted the police acts meant that they aimed to strength the existing hierarchies of race, religion and class rather than encourage the active participation of foreign and alien interests in municipal government. Efforts by communities of Jews and free people of colour from the 1790s onwards to secure civil and municipal rights were repeatedly denied, since these groups made up more than two-thirds of the urban free population and admitting them risked undermining the established political, social and racial order ${ }^{87}$ As noted above, even the cultural solidarity of the white community itself was circumscribed by divisions of wealth, class and social status which worked to disenfranchise all but a small minority of urban residents.

\footnotetext{
${ }^{86}$ Bridenbaugh, Cities in revolt, pp. 100, 102, 104; Benjamin Carp, 'Fire of liberty: firefighters, urban voluntary culture, and the Revolutionary movement', William and Mary Quarterly, 58 (2001) pp. 781-818. Quotation on p. 817. For the 'unacknowledged republic', see Mark Goldie, 'The unacknowledged republic: officeholding in early modern England', in Tim Harris (ed.), The politics of the excluded, c 1500-1850 (Basingstoke and New York, 2001) pp. 153-94

${ }^{87}$ Laura Arnold Leibman and Sam May, 'Making Jews: race, gender and identity in Barbados in the age of emancipation', American Jewish History, 99 (2015) pp. 1-26; Samuel Hurwitz and Edith Hurwitz, 'The New World sets an example for the Old: the Jews of Jamaica and political rights, 1661-1831', American Jewish Historical Quarterly, 55 (1965) pp. 37-56; Holly Snyder, 'Rules, rights and redemption: the negotiation of Jewish status in British Atlantic port towns, 1740-1831', Jewish History, 20 (2006) pp. 147-70; Melanie J. Newton, The children of Africa in the colonies: free people of color in Barbados in the age of emancipation (Baton Rouge, 2008) pp. 59-86; Heuman, Black and White, pp. 4-15, 23-45; Livesay, Children of uncertain fortune, pp. 66-401.
} 
The police acts reflected this attitude, insofar as their aim was to control the urban environment at all costs rather than to encourage active citizenship and democratic engagement. Whereas the Scottish police acts usually had measures allowing for householders and ratepayers to elect police commissioners, the Jamaican acts largely added the new police powers to the existing parish vestries and magistracies, which were staffed by election from a small pool of local white planters, merchants and professionals. In rural parishes the extreme scarcity of whites meant that vestries tended to be more open and egalitarian, and the 'herrenvolk' principle was therefore much stronger, but the concentration of the white population in towns created a critical mass that enabled exclusion rather than inclusion. ${ }^{88}$ The act incorporating Kingston in 1801 allowed the freeholders to elect twelve aldermen and twenty-four common councillors, for instance, but electors had to hold property worth $£ 10$ per year, and 'any person being descended from a negro and not being above three degrees removed ... [and] any person not professing the Christian religion, shall not be entitled to vote nor be eligible to any office'. ${ }^{89}$ Large numbers of poor whites, Jews and free people of colour were therefore to be excluded from voting or holding municipal office. Vestries in Jamaica also annually appointed or elected officers such as the clerk of the peace, the constables and the way-wardens charged with the repair of local roads, and although the police acts created new municipal officers such as the fire-wardens noted above, these too were to be elected by the vestry from the same small circle of local white elites. ${ }^{90}$ Householders were only free to exercise power where it reinforced the social and racial hierarchy. For example, despite the creation of night watches the police acts also gave householders the power and responsibility 'to take up any negro or other slave who shall be

\footnotetext{
${ }^{88}$ Petley, Slaveholders in Jamaica, pp. 62-4; Brathwaite, Creole society, pp. 19-22; James A. Delle, The colonial Caribbean: landscapes of power in the plantation system (Cambridge, 2014) pp. 115-28

${ }^{89}$ Dodsworth, 'Civic' police', vol. iii, 447-8. This was the same franchise as the house of assembly: Brathwaite, Creole society, pp. 44-9; Petley, Slaveholders in Jamaica, pp. 62-4. The franchise in Scottish police acts generally varied between $£ 5$ and $£ 10$ : Barrie, Police development, pp. 132-8

${ }^{90}$ Brathwaite, Creole society, pp. 20-2; Petley, Slaveholders in Jamaica, p. 55
} 
found in the streets, lanes or avenues of the said town [after curfew]' and carry them to the workhouse.

The purpose of the police acts was therefore to support a narrow oligarchy that would maintain social and economic order and direct the threatening forces of revolutionary upheaval along safe channels. In that respect Kingston and other towns in Jamaica probably most closely resembled the 'closed' or 'select' vestries of eighteenth and early nineteenth century England, which were likewise appointed from within a small clique of local elites rather than elected from amongst the freeholders as in 'open' vestries. Though later excoriated by urban reformers in the 1830s as an embodiment of the self-interested partiality, waste and ineptitude of local government under 'Old Corruption', it is increasingly clear that that this process was often driven by a strong conviction among urban elites in the late eighteenth and early nineteenth centuries that the problems of poor relief, urban improvement and municipal governance were best addressed by concentrating key powers in a small, experienced group of local property-holders. ${ }^{91}$ This enabled municipal corporations and parishes to face down pressures to cut back expensive services such as poor relief, and allowed them to maintain a cadre of professional urban officials who could build up experience and expertise rather than a rotating system of amateur officials. Their civic ideals, in other words, were to be expressed through effective paternalistic government rather than noisy and self-interested popular participation, and this attitude obviously overlapped closely with the strong elements of hierarchy which cut across white solidarity and egalitarianism within Jamaica. Though not always evident in the legislation passed during this period, this sentiment emerged far more strongly in the 1830s, when the extension of civil rights to Jews

\footnotetext{
${ }^{91}$ Sweet, English town, pp. 30-3, 56-9, 109, 141-61; David Eastwood, Governing rural England: tradition and transformation in local government, 1780-1840 (Oxford, 1994) pp. 125-32, 175-87; F.H.W. Sheppard, Local government in St Marylebone, 1688-1835: a study of the Vestry and the Turnpike Trust (London, 1958) pp. 21598
} 
and people of colour opened up the franchise and caused concern within the Kingston urban establishment that the disorderly 'rabble' and radical politicians - such as Daniel Hart, 'a Jew pedlar and seller of rotten shads, though with a little money' - were undermining their control of urban politics. ${ }^{92}$

\section{Conclusion}

Around the turn of the nineteenth century Jamaica therefore experienced what might be called a 'municipal moment', as towns obtained police acts which reflected a new awareness of the urban environment as a distinct space in its own right, requiring a comprehensive solution to problems of safety, security, public health, markets and improvement of the urban fabric. The process began in Kingston in the 1780s, where the vestry looked to the assembly for help, and this provided models for other towns in the 1790s as they began to confront similar problems. This was thus a legislative as much as urban development, embodying a new colonial approach towards the powers of colonial legislating. The process peaked in the incorporation of the city of Kingston in 1801, for the purposes of 'police and good government'. Perhaps because other towns in the British West Indies were smaller and felt some of these problems less acutely, they were slower to adopt such comprehensive solutions and continued to employ a piecemeal approach that dealt with individual urban problems as they arose. Even in Barbados, the only town that approached Kingston in size before 1800, measures for watching, rebuilding and otherwise administering the town were passed as separate acts in the 1760 s and 1770 s, as were acts in 1813,1824 and 1834 for a municipal constabulary. ${ }^{93}$ The governor's proposal in 1803 to copy Kingston and incorporate

\footnotetext{
92 See below n. 97

${ }^{93}$ Welch, Slave society, pp. 44-6, 162-5; Claude Levy, 'Barbados: the last years of slavery, 1823-1833', Journal of Negro History, 44 (1959) pp. 337-41; Richard Hall (ed.), Acts passed in the island of Barbados, from 1643 to 1762 inclusive (London, 1764) pp. 436-42; Samuel Moore (ed.), The Public Acts in Force; passed by the
} 
Bridgetown as a city to help it to tackle urban problems fell victim to planters' suspicions of executive power. ${ }^{94}$ Only in Grenada did planters adopt a police act in 1789 , 'for the better regulation of the police of the town of St George', aimed at 'sailors, free coloured men and male slaves, [who] have been and are in the practice of assembling themselves together at late and unseasonable hours and of committing tumults and riots in the different streets and lanes of the town'. The act instituted a curfew for people of colour and banned unlicensed meetings, set up a municipal patrol to enforce it and imposed regulations on the sale of liquor, but lacked the other urban powers typical in Jamaican acts. ${ }^{95}$ Only in Jamaica did the process of urban renewal reach the same level as other areas of the British Atlantic.

Jamaican towns were therefore part of a wider British urban Atlantic which persisted after 1783 and sought similar solutions to municipal problems. ${ }^{96}$ In some cases this amounted to the piecemeal accumulation of statutory authorities but in Scotland and Jamaica the growing power and ambitions of the legislature were used to establish 'police' commissions, either alongside or co-extensive with the existing political structures, for the governing of urban society in its broadest possible sense. Jamaica towns were therefore typical of many other towns in the British Atlantic in their increasing use of legislation, but also equally typical in the fact that the uses they made of it reflected local conditions, in particular a specific view of what it meant to 'police' towns within a slave society and plantation economy. Unlike in Scotland or the United States, supporters had little intention of laying the groundwork for

Legislature of Barbados, from May 11th 1762 to April 8th 1800, inclusive (London, 1801) pp. 22-62, 66-80, 127-47, 208-12

${ }^{94}$ Neville A.T. Hall, 'Law and society in Barbados at the turn of the 19th century', Journal of Caribbean History, 5 (1972) pp. 43-5

${ }^{95}$ George Smith (ed.), The Laws of Grenada, from the year 1763, to the year 1805, with tables of all the Statutes passed in that period (1808), No. LI

${ }^{96}$ Recent work has even extended this to British India: see Jonathan Eacott, 'Urbanity and the endurance of global empire: Charleston and Calcutta before and after the American Revolution', in Joseph P. Ward (ed.), European empires in the American South: colonial and environmental encounters (Jackson, MI, 2017) pp. 21839. 
wider civic participation, though Gad Heuman, Thomas Holt and Swithin Wilmot have demonstrated that once civil disabilities were removed and slavery abolished in the 1830s, urban parishes such as Kingston provided a forum for grassroots political action which enabled newly freed and enfranchised people of colour to learn the ropes of the political process. ${ }^{97}$ Jamaican towns seem instead to have imitated the police commissions in occupied North America and the select vestries of England, which used legislation to empower an urban oligarchy for the purpose of maintaining order among restive populations of black slaves and rootless whites during periods of unrest. In this respect the police acts of Jamaica were not a startling innovation but, as Trevor Burnard has concluded of plantation towns such as Kingston and Bridgetown as a whole in this period, 'an alternative pathway that urban modernity took in the British Atlantic world. ${ }^{98}$

\footnotetext{
${ }^{97}$ Swithin Wilmot, 'From bondage to political office: blacks and vestry politics in two Jamaican parishes, Kingston and St David, 1831-1865', in Kathleen E.A. Monteith and Glen Richards (eds.), Jamaica in slavery and freedom: history, heritage and culture (Kingston, Jamaica, 2002) pp. 307-23; Swithin Wilmot, 'Black voters and Jewish politicians: electoral politics in three Jamaican parishes, Kingston, Portland and St Mary, in the post-slavery period', Journal of Caribbean History, 49 (2015) pp. 30-52; Heuman, Black and White, pp. 5763, 77-8, 93, 99, 103, 120 [Holt 'Problem' pp. 98-103, 216-23.

${ }^{98}$ Burnard, 'Towns in plantation societies', p. 858
} 